\title{
Bir Şairin Gözünden Seksenler: Tufandan Önce Örneği
}

Geliş Tarihi/Received: 15.01.2021 Kabul Tarihi/Accepted: 03.08.2021 DOI: 10.46372 /arts.952908
Dr. Öğr. Üyesi Dursun ŞAHIN

Giresun Üniversitesi

Eğitim Fakültesi, Türkçe ve

Sosyal Bilimler Eğitimi Bölümü

dursunsahin@gmail.com

ORCID: 0000-0001-6932-9486
Doç. Dr. Mehmet ALVER

Giresun Üniversitesi

Eğitim Fakültesi, Türkçe ve

Sosyal Bilimler Eğitimi Bölümü mehmetalver2806@gmail.com

ORCID: 0000-0003-4832-7363

\section{Öz}

Necati Cumalı, şiir, hikâye, roman, deneme, tiyatro, hatıra, senaryo, inceleme gibi pek çok türde eserler vermiş bir sanatçıdır. Cumalı üzerine yapılan çalışmalarda daha çok roman, hikâye ve tiyatroları üzerine yoğunlaşıldığı görülmektedir. Bu çalışmada sanatçının şiirleri üzerine bir inceleme yapılmaya çalışılacaktır. Cumalı, şiirlerinde bireysel konulara, gündelik hayata, toplum ve dünya gerçekliğine yer vermiş bir sanatçıdır. Sanatçının Tufandan Önce adlı șiir kitabı da ciddi bir travmanın yaşandığı 12 Eylül 1980 Darbesi sonrasında sosyal hayata şair gözüyle bakmaktadır. Kitapta yer alan şiirlerde darbe, gençlik, teknolojik gelişmeler, cinsellik, Anadolu kadını, İzmir, ölüm, dostluk, üretim gibi temalar ön plana çıkmaktadır. Çalışma, Cumalı'nın Tufandan Önce'de yer alan şiirlerinde toplumsal gerçekliğin hangi ölçüde yer aldığını ve nasıl bir tutumla ele alındığını toplumsal eleştiri kuramı çerçevesinde değerlendirmeyi amaçlamaktadır. Bu doğrultuda devir, şahsiyet, eser sırası takip edilecektir. Önce durum tespitiyle devrin analizi yapılacak, ardından sanatçının edebi kişiliği üzerinde durulacaktır. Son olarak da sanatçının şiirlerinden seçilen örnekler içerik yönünden tahlil edilerek Cumalı'nın dönemine tanıklığı ve meselelere bakışı irdelenecektir.

Anahtar Kelimeler: necati cumalı, seksenler, tufandan önce, şiir.

Şahin, D., Alver, M. (2021). Bir Şairin Gözünden Seksenler: Tufandan Önce Örneği. ARTS: Artuklu Sanat ve Beşeri Bilimler Dergisi, Necati Cumalı Özel Sayısı, ss. 90-108. 


\title{
The Eighties Through the Eyes of a Poet: Example of Tufandan Önce
}

\begin{abstract}
Necati Cumalı is an artist who has produced works in many genres such as poetry, stories, novels, essays, theater, memoirs, screenplays and studies. It is seen that the studies on Cumalı mostly focus on novels, stories and plays. In this study, an examination will be made on the poems of the artist. Cumalı is an artist who has included individual issues, daily life, society and world reality in his poems. The artist's poetry book, Tufandan Önce, also looks at social life as a poet after the September 12, 1980 coup, when a serious trauma was experienced. In the poems in the book, themes such as coup, youth, technological developments, sexuality, Anatolian women, izmir, death, friendship and production come to the fore. The study aims to evaluate the extent to which social reality takes place in Cumalı's poems in Tufandan Önce and what kind of attitude it is handled within the framework of social criticism theory. In this direction, the order of transfer, personality and work will be followed. First, the analysis of the period will be made with due diligence, and then the literary personality of the artist will be emphasized. Finally, the samples selected from the artist's poems will be analyzed in terms of content, and Cumali's testimony to his period and his view of the issues will be examined.
\end{abstract}

Keywords: necati cumalı, eighties, tufandan önce, poem. 


\section{arts}

\section{Gíriş}

Sözlü ve yazılı verimler yoluyla bir toplumun kültürel birikimini şekillendiren, duygu ve hayal dünyasını şekillendiren edebiyat, toplum hayatını derinden etkileyen her şeyi konu edinmektedir. Toplum hayatında ortaya çıkan savaş, siyasal gelişme, göç, din, medeniyet değişimi vb. ögeler, edebî ürünlerde yoğun bir biçimde yer almaktadır. Bu durum edebiyat toplum ilişkisinin boyutlarını gösterir niteliktedir.

Edebiyatın gözden kaçırımaması gereken yanlarından biri de toplumsal duyarlıık kazandırmadaki gücüdür. Acıma, sevinme, üzülme, başkalarının acılarına ortak olma, güzellikler karşısında etkilenme gibi duygusal durumlar ancak duyarlıkların bilincine varmış kişilerde görülebilir. Bu bilincin oluşmasında edebiyat ürünlerinin de payı vardır. Bu durumu Bülbül, Türkoğlu ve Küzeci $(2015$, s. 2) şu şekilde özetlenmiştir;

Edebiyatın toplumsal işlevinin büyük sorumluluklar üstlendiği bilinmektedir. İnsanı çevresiyle birlikte değiștirip bilinçlendirmede en etkili öğelerden biri de edebiyatın mucizevî gücüdür. Edebiyatın yöneldiği ortam, insan ve onun doğası olduğuna göre, işlevini gerçekleştireceği ortam da burası olacaktır. İnsana yönelik bir sunudur edebiyat. Bu davete yönelmediği zaman insan, yazının verimliliği ortadan kalkabilir ve belleğini yitirebilir. Her dönemde yaratıcı ve yönlendirici gücüne tanık olduğumuz edebiyat/yazın, gücünü yenilemesi için, yitirdiği belleğe geri dönmelidir. Bu zorlu burgacı, ancak okurla buluşacağı yaratı noktasında aşabilecektir.

Sanatın sanat için mi yoksa toplum için mi olacağı tartışmalarının geçmişte kaldığını ifade eden Orhan Okay, bir sanat eserinin ne kadar bireysel olsa da o eserde mutlaka bir sosyal yan olduğunu; aynı zamanda bir eser her ne kadar belli bir ideolojinin propagandasını yapar nitelikte olsa da o eserde yine bireysel bir içerik olduğunu dile getirir (Okay, 1990). Okay ayrıca gerçek büyük eserlerde sadece o eseri oluşturan sanatçının değil, aynı zamanda hem bütün insanlığın hem de sanatçının içinden çıktığı ulusun katkısı olduğunu vurgular (Okay, 1990). Okay'ın bu tespiti bir edebi ürünün hem bireysel hem ulusal hem de evrensel olduğunu göstermektedir. Bu da edebi eserin her ne olursa olsun sosyal gerçeklikten bağımsız olamayacağını göstermektedir.

Edebî eserle sosyal yapı arasındaki ilişkiyi daha da ileri götüren Çelik (2013), edebi eserin mutlaka bir toplumsal yapıyı veya kabuller zincirini yansıtacağını vurgular. Çelik (2013), metinlerde sözü edilen sosyal olayları algılama basitliği dışında, şïrde 
veya anlatı türündeki eserlerde yer alan karakterlerin ve buna bağlı olarak şair ve yazarların hayata bakış açılarının ve sahip oldukları değerlerin, eserin sosyal zeminini oluşturduğunu, her roman, hikâye kahramanı veya şïre konu edilen kişi veya kişilerin, birer bireysel ve toplumsal değerler dizisini yansıttığını, bu yüzden onların, tüm iyi ve kötü yönleriyle, edebiyat sanatçısının belleğindeki toplumsal birikimlerin izlerini taşıdıklarını söyler.

Edebiyat toplum ilişkisi bağlamında vurgulanan bir diğer durum da sanatçının, döneme tanıklığıdır. Alver (2006, s. 110) de edebiyat ile hayat arasında bağlantı/ irtibat kurmaya çalışan girişimlerin çoğunlukla edebiyatın "tanık" olma yönünü öne çıkardığına dikkat çeker. Alver (2006, s. 111) ayrıca edebiyatın sadece hayatı (toplumsalı) yansıtmadığını, onu anlatmadığını, yaşam tarzlarını biçimlendirip hayatı şekillendirdiğini de ekler.

\section{Seksenli Yıllar}

Cumalı' nın 1983 yılında yayımladığı Tufandan Önce adlı şiir kitabı, seksenlerin ilk yıllarında yaşanan travmaları gözler önüne sermektedir. Dünyadaki kültürel gelişimin ve Türkiye'de yaşanan 12 Eylül 1980 darbesinin etkisiyle seksenli yıllar Türkiye'si değişik iktidar projelerine, söz siyasetine ve kültür stratejilerine sahne olmuştur. Bu dönem, bir yandan baskılar ve yasakların dönemi, diğer yandan da yasakların yerine dönüşümü hedefleyen, ortadan kaldırmak yerine yaşatmayı vaat eden siyasal hareketlerden oluşmaktadır. Sever (2019)'e göre seksenlerin belirgin özelliklerinden biri de geçmişe duyulan ilginin artmasıdır. Sever (2019) ayrıca böyle bir kültür atmosferi içinde 68 kuşağının tarihi ağırlığının içinin boşaltıldığını, içeriksiz bir ruha, seçkin bir kuşak ideolojisine dönüşebildiğini vurgulamaktadır.

Seksenlerde Türkiye'de o döneme kadar "mahrem" kabul edilen birçok konunun ilk kez kamuoyunun gündemine geldiği görülür. Gürbilek (2001, s. 22), cinselliğin ilk kez bu kadar büyük bir ısrarla söze döküldüğünü, cinsel eğilimlerin sınıflandırıldığını, kuşakıarın ayrıştıııdığını belirtir.

Tarımda makineleşmenin, sanayileşmenin artmasıyla köyden kente göç hareketiyle birlikte şehirlerde yaşayanların oranı 1980'lerde \%50'dir. Bu göç 
hareketinde şehirlerin çekiciliğinin yanı sıra şehirlerde iş gücüne duyulan ihtiyacın artması önemli bir etkendir. Köylerden şehirlere göçün artması, kenar mahallelerde gecekondulaşmayı artırmıştır. Zaman içinde göçler köylerden şehirlere göçle sınırlı kalmaz. Küçük şehirlerden büyük şehirlere göçler de hızlanır. Şehirlerin yapısında ekonomik, siyasal ve kültürel uyumsuzluklar, çatışmalar görülmeye başlanır. Uyuşturucu ticareti, fuhuş gibi yasal olmayan işlere dair haberler, seksenli yıllar gazetelerinde önemli bir yer tutar.

12 Eylül 1980 darbesinden üç yıl sonra 6 Kasım 1983'te yapılan seçimlerde Anavatan Partisi iktidara gelir. Darbe sürecinin yarattığı gergin ve yasaklı günlerden demokrasiye geçişi vaat eden bu dönemde yaşanan hızlı değişimi Sever (2019, s. 5-6) şöyle özetler:

(...) kamu bankaları denetim-dışı bırakılarak soyulmalarının kolaylaştırıması; servet beyanının kaldıııması; mevduat sertifikası, sırdaş hesap gibi isimsiz hesapların açılması, böylece kara para aklama işinin kolaylaştırıması olanakı hale getirilir; paranın kaynağının sorgulanması kaldırlır. Burada borsaclık faaliyetlerini, bankerleri, bankerzedeleri anmak gerekir. Daha sonra filmlere, romanlara konu olmuş bir faize yönelme, çalışmadan, üretmeden para kazanma amacıyla her yolu mübah görme, toplumsal yapıda derin yaraların açılmasına, intiharların, cinayetlerin vukuu bulmasına neden olur. Terör örgütü PKK'nın uyuşturucu ticaretine girdiği bu dönemde, uyuşturucu ticareti toplumun diğer kesimlerini de etkisi altına alırken uyuşturucuda örgütlü kaçakçılık suçlarından idâm cezası kaldırılır. İhracałı artırmak için yapılan vergi iadesi yaftası altındaki malî teşvikler, hayalî ihracatı özendirirken ve birçok kişi, şirket kaçakçlıkla suçlanırken, suç dosyaları rafa kaldırlır ve zaman aşımına uğraması sağlanır. ABD'nin "Yeşil Kuşak" olarak adlandırdığı projesine paralel uygulamalara gidilir. Tarikatların yaygınlaşmasının ve serbest faaliyet göstermelerinin önü açılır, Kur'an kurslarının, imam hatip okullarının sayısı arttıılır. Diğer okullarda da din dersi zorunlu hâle getirilirken felsefe dersi zorunlu olmaktan çıkarılır.

Kolay yoldan lüks bir yaşama ulaşma, zengin olma, toplumda farklı, yani statü yönünden üstte olma düşüncesiyle ve amacıyla insanlar her yolu ve yöntemi "geçerli" sayarak hareket ederler. Pahalı ve markalı ürünler almak, başła yönetenlerin tavrı olur; ki halkta da bu yönde adeta bir yarış başlar ve "köşeyi dönmek", "iş bitirmek, iş bitirici olmak" tabirleri, bu dönemde makbul olan genel geçer tavrın adı olur. Kendi sorunlarından, ihtiyaçlarından ülkenin içinde bulunduğu şartlardan habersiz, apolitik bir insan tipi gelişir. Zahmetsiz her şeye sahip olma düşüncesinde, emeğe saygısız, üretmeyen, adeta düşünmekten kaçınan, topluma katkı sağlamayan bireylerin çoğunluğu oluşturduğu bir toplum yapısına ulaşilır.

Çünkü küreselleşmenin öngördüğü serbest piyasa ekonomisinde "[b] ireycilik, kültürsüz bencillik ve para hırsı" (Kazgan, 2006: 124) bunu gerektirir ve toplumsal yaşamda tüketen, tükettikçe statüsünün yükseldiğini zanneden bir insan tipi yaygınlaştırıı. Bilgiye ulaşmaya çalışan ve bilgilenmeyi bir erdem olarak benimseyen insanın (homo sapiens'in) yerini imaja, görüntüye 


\title{
$\operatorname{arts}=$
}

\begin{abstract}
önem veren insan (homo videns) almaya (Sartori, 2004: 11) başlar. Henüz, geleneksel değerleriyle düşünen ve kanaat ederek geçinen, şükreden, bilinçaltında "Yerli malı, yurdun malı" anlayışını koruyan Türk insanını tüketime, bu tüketimi çılgınlık düzeyinde gerçekleştirmeye, farklı olmaya, markaya ve lüks düşkünlüğüne yönlendirmek yönünde medya, medyadaki haber ve reklamlar, yoğun şekilde kullanılır. Kredi kartları, taksitli satışlar, çeşitli kampanyalar tüketimin artmasını sağlayıcı araçlardır. 12 Eylül 1980 öncesi sokağa çıkamamaktan, tüp, yağ, akaryakıt, vd. kuyruklarından, yoğun politize oluştan bunalan insanlar, bu dönemde her şeyde bolluğa erişir, kıt-kanaat yetinme, şükretme yerine tüketerek, lüks yaşayarak, eğlenerek yaşamaya başlar.
\end{abstract}

Seksenli yıllardaki hızlı değişim ve yenilikler, tüketim çılgınlığı olarak adlandıııan bağımlılık türünün halk arasında yaygınlaşmasına, buna bağlı olarak da kısa sürede ailevi değerlerin yozlaşmasına ve toplumsal çöküşe neden olmuştur. Cumalı'nın Tufandan Önce'si de toplumsal çöküşe sitem ve öfke niteliği taşımaktadır.

\section{Necati Cumalı'nın Şiir Dünyası}

1940'll yıllar, şiirde hem şekil hem de içerik olarak arayışların ön plana çıktığı yıllardır. Cumalı da o yıllarda yeni bir şiir arayan şairler arasında yer almakta, kendi şiirinin temellerini kurmaktadır. Doğan Hızlan'ın kendisiyle yaptığı röportajda çevresinde, yaşamında şiiri aradığını belirten Cumalı, çocukluk anılarından öğrencilik yıllarına kadar her şeyi kendi yaşamından şirleştirdiğini, kimseyi taklit etmediğini, daha sonra İkinci Dünya Savaşının etkilerini yansıtmaya çalışı̆̆ını, devamında ağıllaşan yaşam koşulları içinde barışa dönüş duyarlığı ile yazdığını, her kitabında kendinden uzaklaşmadan kendini yenilediğini anlatır (Hızlan, 1981).

Cumalı'nın Karakolda adlı şirini inceleyen Kaplan, onun basit şive taklitlerine gitmediği şiirini sade ve çıplak olarak nitelendirirken, onun şiirinin yapısında dram ve mizansen tekniğinin rolü olduğunu belirtir (Kaplan, 1992)

Sazyek (2006), Cumall'nın başła Garipçiler olmak üzere Sabahattin Eyüboğlu, Bedri Rahmi Eyüboğlu, Cahit Sıtkı Tarancı, Erol Güney gibi isimlerle 1946 seçimlerinin ardından muhafazakâr siyaset anlayışının yeniden ön plana çıktığı bir süreçte ülkenin sosyal ve siyasal gidişi üzerine düşüncelerini ortaya koymak amacıyla Yaprak dergisi etrafında bir araya geldiklerini belirtir. Bu tespit, Cumalı'nın eserlerinde sosyal gerçekliğin boyutunu da ortaya koymaktadır. 


\section{$\operatorname{arts}=$}

Korkmaz ve Özcan (2006) da Marksist ifade biçimini çoğu zaman estetik bir kalkan olarak alan ama uygulamada çok daha serbest duyumları olan Necati Cumalı şiirinin en önemli özelliğini hayatın içinde yer alan küçük ayrıntıların diyalektik bir mantıkla görünür hale dönüştürülmesi olarak görürken onun şiirlerindeki betimleme alışkanlığının öykücü kimliğinden beslendiğini, şiirlerinde yer alan kadın figürünün Marksist ideolojinin biçimlendirdiği kadın figürü olmadığını, daha çok anlatım nesnesi olduğunu ifade etmektedirler.

Cumalı, toplumsal duyarlıı̆ıyla ön plana çıkan sanatçılardan biridir. Bu durumla ilgili olarak Oktay (1993, s.523-524), sanatçının toplumsal sorumluluğu düşüncesinin Cumalı'nın ödün vermediği bir konu olduğuna dikkat çekerek onun şiirlerinde bireysel sorunlara, yaşadığı dönemin kendi dünyasının şekillenmesindeki etkilerine değindiğini, ilk şiirlerinde, yaşadığı taşra ortamından, taşra hassasiyetinden manzaralar sunarken her olguyu şiire konu yaparak güncel olanı bırakmadan, özellikle söylevci bir konum ile güncel meselelere değindiğinde hiciv ve ironiden yararlanmayı tercih ettiğini vurgulamaktadır.

Şair, I. Yeni şairlerinin gündemde olduğu bir dönemde şiirler kaleme almış olmasına rağmen yer yer şiirde imgelerden yaralanma ve şiiri düz yazıdan uzak tutma açısından onlardan farklı bir çizgide ilerlemiştir. Ona göre kendisinden iki üç yı önce şiir yayınlamaya başlayan Garipçilerin şiirleri de düzyazıya çok yakındır ve onlar da deyişlerini olgunlaştırma çabası içindedirler (Hızlan, 1981, s. 7). Aynı zamanda biçim ve içerik açısından etkilenmiş olsa da İkinci Yeni şiirinin kapalıı̆ı ön plana çıkaran aşıı imgeci şiir anlayışına da mesafeli olmuştur. Cumalı, bu durumu Hızlan'ın (1981, s. 7) kendisiyle yaptığı röportajda "yeni bir şiirin özünü, içeriğini, bu içeriğe uygun biçimini hep birlikte arama süreci" olarak tarif eder.

\section{YÖNTEM}

Çalışmada, edebiyatın tek başına var olmadığını, toplum içinde doğduğunu dolayısıyla toplumun ifadesi olduğunu savunan sosyolojik eleştiri kuramından hareket edilmiştir. Bu doğrultuda edebi eser, kuramdan hareketle, sosyal koşullar göz önünde bulundurularak incelenmeye çalışılmıştır. 
Araştırmanın yöntemi, nitel araş̧ırma yöntemlerinden doküman incelemesidir. Doküman incelemesi, araştırılan olgu, olay veya durumla ilgili bilgi içeren yazılı veya görsel materyallerin analizidir (Yıldırım ve Şimşek, 2006). Ayrıca bazı şiirler de tahlili metinde yer alan her şeyin anlamlandırıması ve bütün bunların şair veya yazarın davranış tarzına bağlanması, bütün ile parçalar arasındaki münasebetin meydana çıkarıması esasına dayandıran, eseri devir-şahsiyet-eser üçlemesinde değerlendirmek gerektiğini söyleyen (Kaplan, 1988, s. 7-9) Kaplan'ın şiir tahlil metoduyla tahlil edilmiştir.

\section{BULGULAR VE TARTIŞMA}

Cumalı'nın 1984 Yeditepe Şiir Armağanı'nı kazanan Tufandan Önce adlı şiir kitabı, 1983 yılında, 12 Eylül 1980 askeri darbesinden üç yıl sonra Anavatan Partisi'nin iktidara geldiği yıl yayımlanır.

Cumalı'nın Tufandan Önce adlı eserinde 11 adet şiir yer almaktadır. Bunlar:

1. Tufandan Önce

2. Halı

3. İmir

4. Ben

5. Odaya Düşen Uçak

6. Ölü

7. Rüzgâr

8. Sonumuz Bu mu?

9. Pir Sultan Abdal

10. Dost

11. Taşı Delen Buğday

Şengül (2016, s. 318), dönemi etkileyen en önemli olay olarak gördüğü 1980 askeri darbesi nedeniyle 1980 Kuşağı şiirini tahlil edebilmek için o günün sosyolojik yapısını ele almak gerektiğine dikkat çeker. Cumalı'nın serbest yazılmış bu şiirlerine genel olarak bakıldığında da dönemin ruhunu yansıttıkları, sosyal hayatın travmalarına yer verdikleri görülür. 


\section{$\operatorname{arts}=$}

Moran (1988, s. 73), sosyolojik eleştiriyi betimleyici, bazen değer yargıları verse de eser hakkında bir değer yargısı taşımadan durumu tespit etmekle yetinen bir eleştiri olarak görür. Demir $(2015$, s. 150) de darbenin yarattığı kaotik atmosferin, şiirin poetik anlamda farklı yönsemeler içerisine girmesine gerek içerik gerek üslup bakımından yeni yorumların ortaya çıkmasına zemin hazırladığını belirtir. Cumalı'nın şiirlerinde bir durum tespiti yapılacak olursa darbe, tüketim çılgınlığı, toplumsal yozlaşma, medyanın kitleler üzerindeki etkisi, çarpık kentleşme, gençliği olumsuz etkileyen uyuşturucu bağımlıı̆ı, futbol merakı, evden kaçan kızlar, işsizlik, farklı cinsel eğilimler gibi seksenli yıllara dek şiirde pek rastlanmayan konuların varlığı dikkat çeker. Bununla birlikte Cumalı, şiirlerinde her türlü olumsuz atmosfere rağmen örneklerde de görüldüğü üzere umutsuz bir tavır sergilemez.

Cumalı'nın ele aldığı konularda sosyal gerçekliğin yerinin daha iyi anlaşılabilmesi için, Moran'ın ifade ettiği durum tespitine, örneklemeye ihtiyaç vardır. Bu nedenle Cumalı'nın şiirlerinden elde edilen bulgular aşağıda örneklendirilmiş, gerekli durumlarda Kaplan'ın şiir tahlil yöntemi çerçevesinde tahlil edilmiştir. Şairin içinde İngilizce bölümlerin de yer aldığı Tufandan Önce başlıklı şiiri darbe öncesinin tedirginliği, korkusuyla başlar (Cumalı, 1983, s. 9):

Sabah gazeteleriyle çalıyorlar kapımızı

Radyo ile TV ile giriyorlar odalarımıza

Sokağa çıksak rahat bir merhaba

dediğimiz yok birbirimize

Eve girsek karı koca çoluk çocuk

Karşılıklı ne dediğimizi duyamıyoruz

Önümüzde ardımızda karaltılar gölgeler

Kulaklarımızda sesleri gürültüleri

...

Not defterlerimizin yapraklarına uzanmışlar

Sayfayı çevirsek kalkıp doğruluyorlar

Telefonu açtık mı alıcıda sesleri

işaret parmakları gözlerimizin içinde

Nedense kaşları her zaman çatık

Söyledikleri her söz azar

Bağırıyorlar:

You!

İndir yakalarını 
Şapkanı çıkar!

.

Şiirde işsizliğe, baskılara yer verilirken, "serseri kerata", "hayvan oğlu hayvanlar" gibi hakaret ifadeleri, emir cümleleri ve arananların varlığı da darbe günlerinin havasını yansıtır niteliktedir (Cumalı, 1983, s. 10):

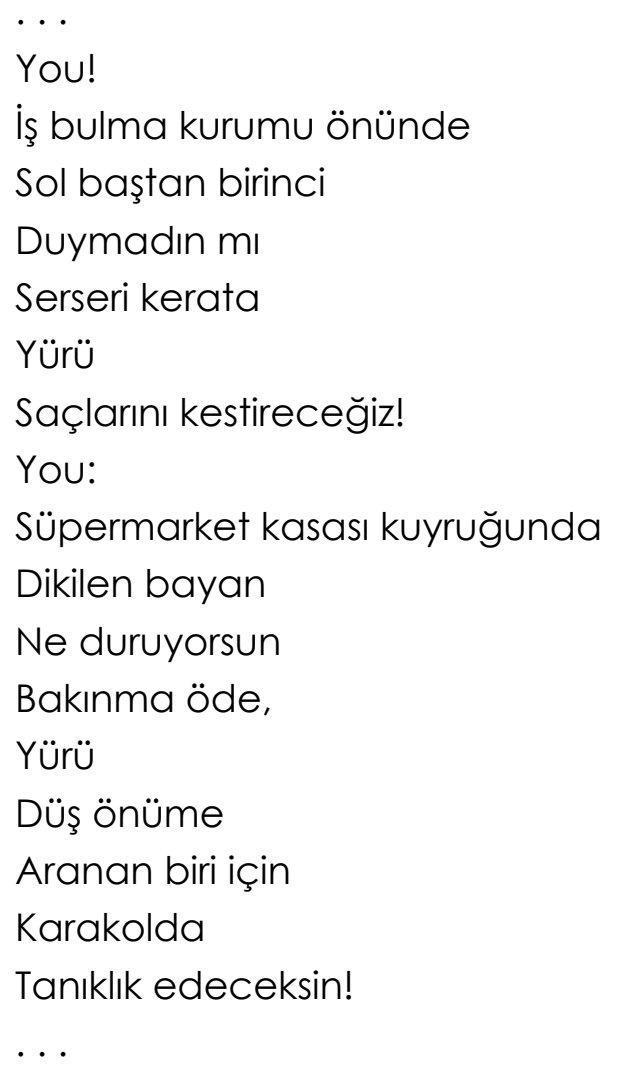

Toplumun tüm kesimlerine bir biçimde etki eden 12 Eylül sonrası dönemde apolitik, tüketimi önceleyen, toplumsal bağları çözülmüş, bireyci bir insan tipi, muteber vatandaş olarak topluma dayatılır (Demir, 2015, s. 146). Seksenli yılların tüketim çılgınlığı ve toplumsal yozlaşmanın ayak izleri de medyanın kitleler üzerindeki tahakkümü de ihmal edilmemiştir (Cumalı, 1983, s. 11):

Yüzde on ön ödeme

Gerisi on üç ay taksitle

Atın değiştirin düşünmeyin!

..

Sizin bankanız

Sizin buz dolabınız

Sizin gazeteniz!

Reklam I dizi film

Reklam I dizi film 


\section{arts}

..

Cumalı, şair gözüyle, gördüğü manzaralardan memnun değildir. Bir yandan da çarpık yapılaşmanın hız kazandığı bir dönem olarak seksenli yıllar insanına kendince uyarılarda bulunmayı da görev bilir (Cumall, 1983, s. 12):

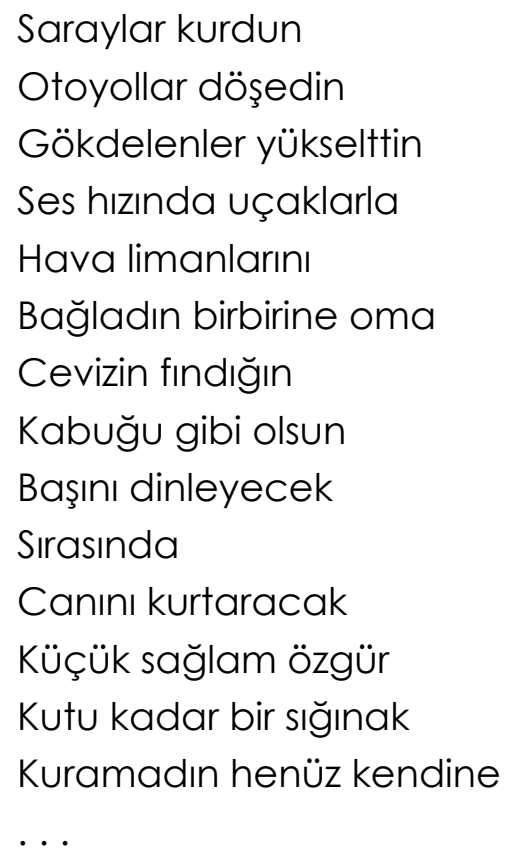

Seksenli yıllar, yozlaşan gençliğin uyuşturucu batağına saplandığı, şaire göre futbol gibi boş işlerle meşgul olduğu yıllardır. Uyuşturucu ticareti, fuhuş, vd. gayr-ı meşru işler adeta işkolu durumuna gelir. Bu, bireyin yaşadığı topluma, hatta kendisine yabancılaşması, normal olandan sapmasıdır (Sever, 2019, s. 6). Cumalı, gençleri bu durum karşısında uyarmaya çalışır (Cumalı, 1983, s. 13, 14):

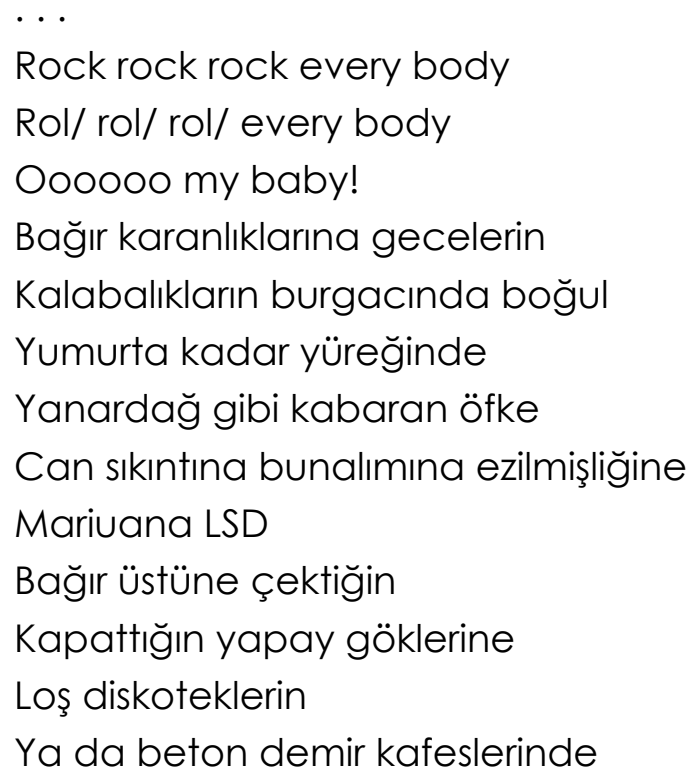


Yüz binlik tribünlerin

Goool, goool, gooool!

...

Kim etmiştir

Senin kendine ettiğini

Binlerce yıldır ölürsün

Sağ kalır cellatların

Ardında!

- .

Cumalı'da yer yer Toplumsal Gerçekçi şiir anlayışının izleri de görülür. Hem dünyada hem Türkiye'de o yıllarda makineleşmenin, sanayileşmenin sonucu olarak işini kaybetme tehlikesiyle karşı karşıya kalan insanların çaresizliği de gözler önüne serilir (Cumalı, 1983, s. 14):

Ey bu kuşkulu çağın

Güvensiz günlerin

Garip insanı

Bak yarattığın robotlar

İsini alıyor elinden fabrikalarda

Sıkıştırdın mı son vidasını

Taktın mı pilini

Parmak uzatıyor

Kapıyı gösteriyor sana!

...

Gürbilek (2001) 'in cinselliğin ilk kez bu kadar büyük bir ısrarla söze döküldüğü, cinsel eğilimlerin sınıflandırılığı dönem olarak belirttiği seksenlerin bu yönü Cumalı şiirinde de yerini bulmaktadır (Cumalı, 1983, s. 16):

..

Mutluluk diye

Bir cinselliğin kaldı elinde

Oyna oyalan

Doğum kontrol hapları

Eşcinselliğin incelikleri

Temeli yarattığın

Sanatın edebiyatın

Seri malı videolu kaset

Sinemada büyüyen perde

Şair her şeye rağmen umudunu yitirmek istememektedir. Kendine göre 


\title{
arts $=$
}

seksenlerin tüm olumsuzluklarını sıraladıktan sonra son bir çağrıda bulunur. Zaman geçmeden bu olumsuzluklardan kurtulmak mümkündür (Cumalı, 1983, s. 17):

\author{
You! \\ it o burnunun ucuna uzanan eli \\ Uykuların kaçtıkça \\ Gece tek başına yatağında \\ Sor kendi kendine \\ Binlerce yıllık tarihsel gelişimle \\ Geleceğin yer bu muydu? \\ Bir çıkmazda mısın \\ Bir bunalım \\ Bir karabasan mı \\ Görüp geçirdiğin, \\ Bir yol ayrımı mı? \\ Sor: \\ İnanacak misın yine kendine, \\ Ruhunu kurtaracak misın?
}

Tarihin her aşamasında gerek motiflerinin zenginliği gerek maharet isteyen incecik dokuma yöntemleriyle dikkat çeken, geleneksel kültürde ayrı bir yere sahip olan halılar da şairin Halı adlı şiirinde, farklı bir amacın malzemesi olur. Seksenlerin dramatik durumlarından biri olan Anadolu'nun farklı noktalarından büyük şehre kaçan genç kızların gerçekliğini anlatmada bir araç olarak da yer alır. Tufandan Önce şiirinde olduğu gibi Halı şiirinin sonunda da pişmanlık ve sitemle birlikte bir uyarı kendini gösterir (Cumalı, 1983, s. 22):

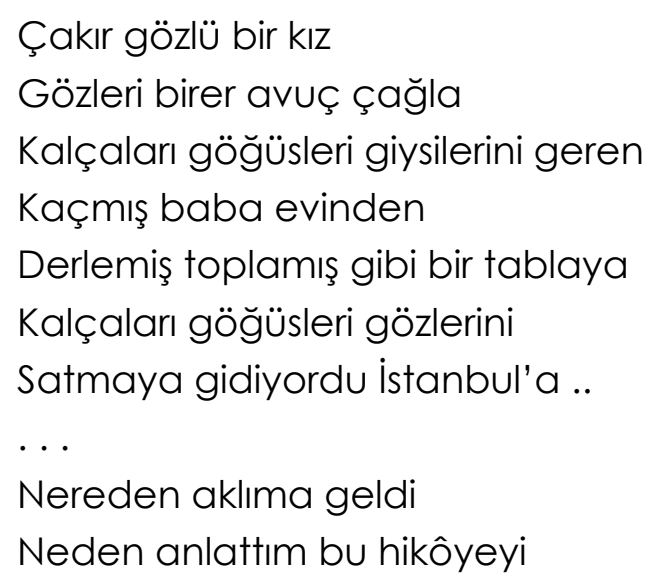


Belki de gözlerim halıda

Dallara çiçeklere takıldı

Bir ağaçıı o kı da

Ak pembe çiçekler açar

Yeşil çağlalar verirdi..

...

Söyle neyi kanıtlayacaksın

Anıların 'küllerini karıştırmakla

Kal dediği yerde sevdiğin sesin

Kalman gerekirdi

Yürüdün gittin

Koskoca bir dünyaydı kollarını açtığın

Ne geçti eline kavuşturduğunda?

Tüm özlemlerin dokuduğun halıda..

Çocukluk anılarından öğrencilik yıllarına kadar her şeyi kendi yaşamından şiirleştirdiğini söyleyen İzmir adlı şiiri de bu anlayışla kaleme aldığı şiirlerdendir. Ben şiiri de yine darbe öncesi yılların tedirginliğini tüm çıplaklığıyla ortaya koymaktadır (Cumalı, 1983, s. 30):

..

Aklımdan gecen her eylem suç

Dilimin ucuna gelen her söz küfür

Yasak tümü yasak düşündüklerimin

Uyuşturucular ateşli silahlar gibi yasak

Aklımdan geçenleri kalksam söylesem

En hafifi zinadan altı ay yerim

Kimsin sen nesin necisin

Düşler ardında bir şair

Alt yanı sakarın hırçının biri

Ne görsen dert edersin kendine

Madem yerini ezilenler arasında seçtin

Ezilenlerle 'birlikte sen de ezileceksin

$\cdots$

Cumalı, şiirlerinde yer yer ironik söylemlere de yer vermektedir. Ülkenin içinde bulunduğu çarpıklıktan çıkış yolunu da ironik bir üslupla gösterir (Cumalı, 1983, s. 31):

Yasaklar örgüsü tüm yasalar

Suç işlemek bir hüner bir inceliktir

Camilerde açılış törenlerinde görün

Bağışta bulun hayır kurumlarına 


\section{arts}

Gülümse suçlarına kendinden güçlülerin

Dilediğin suçu işle sana kim ne der

..

Odaya Düşen Uçak'ta teknoloji, hasret, ölüm, çaresizlik vurgusu yapan Cumalı, Ölü'de yaşamının hızla tükendiğini, Rüzgar'da kışın gelişini birkaç dizeyle anlatır. Şairin düzensiz uyaklarla bezediği Sonumuz Bu mu şiiri de çağa sitem niteliğindedir (Cumalı, 1983, s. 37):

Gençlikte ne varsa inandığımız İyi doğru güzel bellediğimiz Kırıldı döküldü hoyrat ellerde Ayaklar altında çiğnendi şiir Geçerli tek uyak paranın sesi

Ayaklar altında kutsal ne varsa Dostluklar yeminler pörsümüş Aşklar kabuğu sıkılmış posa Kalpler sevgilere sağır Acımanın kapıları kapalı Kaba kahkahalar sardı kenti ...

Pir Sultan Abdal şiirinde Pir Sultan Abdal'ın idamını canlandırırken onun Ölmediğini bir deniz feneri gibi yol gösterdiğini, ışı̆̆ının yarınları aydınlattığını dile getirir (Cumalı, 1983, s. 37):

Sorun ölmek midir ki Sönmektir Dede Sultan Uzat elini bize Karanlıklardan geçir

Dost'ta paylaşmayı, başkalarını da düşünmeyi öğütleyen Cumalı, son şiiri Taşı Delen Buğday'da çizdiği tüm olumsuz manzaralara rağmen hala umudunu yitirmediğini göstermektedir. Bu durum şairin sadece şiirlerin kendi içinde değil, şiir kitabında yer alan şiirlerin sıralanmasında da bilinçli bir tavır sergilediğini göstermektedir. Şair tam yaşamdan umudunu kesmişken bir buğday tanesi yeniden umut olur (Cumalı, 1983, s. 7): 


\title{
arts
}

\author{
Fısıltısını duydum yanıbaşımda \\ Ayağımın dibinde gördüm \\ Uzamış tek başına taşı delmiş \\ Ufacık tane buğday \\ Tay duran bebekler gibi \\ Uzatmış küçücük ellerini \\ Gülüyor güneşe rüzgara bana \\ Yıkıntılar arasında kararlı \\ Büyüyecek talihini deneyecek \\ Diyordu ki yaşamak \\ Karanlık yer altında \\ Çürüyen tohumdan çıkarak \\ Başak olmak savrulmak \\ Işıklı göklere sonsuzluğa \\ Güzel bir yolculuk değil mi \\ Güldüm söz verdim ilkyaza \\ Harmanına gidecek \\ Sağlığına içeceğim
}

\section{SONUÇ}

Necati Cumalı'nın 1983 yılında yayımladığı Tufandan Önce adlı şiir kitabını sosyolojik eleştiri kuramı çerçevesinde, Mehmet Kaplan'ın şiir tahlil metodundan da yararlanarak doküman incelemesi yoluyla irdelemeyi amaçlayan bu çalışmada öncelikle edebiyat toplum ilişkisine yer verilmiştir. Devir-şahsiyet-eser üçlemesinden hareket edilerek öncelikle çalışmada ele alınan eseri şekillendiren dönem, şiirlerde ele alınan konular da dikkate alınarak gözler önüne serilmiştir. Daha sonra Cumalı'nın edebi kişiliği, içinde bulunduğu dönemle ilişkilendirilerek ve şiirleri üzerine bir çalışma olduğu için şair kimliği ön plana çıkarılarak ele alınmıştır. Son olarak da Moran'ın (1988, s. 73) sosyolojik eleştiride durum tespiti olarak nitelendirdiği eser örneklemelerine ve değerlendirmelere yer verilmiştir.

Çalışmada elde edilen bulguların farklı çalışmalarda ortaya konan sonuçlarla da ortaklıklar taşıdığı görülmüştür. Örneğin 1980 sonrası şiiri üzerine tasnif çalışması yapanlardan şair, eleştirmen K. Celal Gözütok'un on gruba ayırdığı' 1980 sonrası

1. Herkesin rahatını kaçıran kopuşun şiiri, şimdiki zamanın ve geleceğin vaat ettiği kırtasiyeci toplum modellerini 


\section{arts}

şiirinin ilk grubu, Cumalı'nın bu çalışmada incelenmeye çalışılan şiir anlayışının yer aldığı grup olarak değerlendirilebilir.

Gözütok bu grubu, herkesin rahatını kaçıran kopuşun şiiri, şimdiki zamanın ve geleceğin vaat ettiği kırtasiyeci toplum modellerini reddeden, yan etkileri çok ağır olan yeni hayatın içinde bir daha dönebileceği baba ocağı olmayan, atılmış gerçek bireyin tehlikeye girişini sorgulayan şiir olarak nitelendirir. Ona göre bu şiir, canhıraş bir söylemin ve sosyal nefretin şiiridir (Gözütok'tan aktaran Demir, 2015, s. 153). Cumalı'nın incelenen eserdeki tavrı da 1980 sonrası oluşan sosyal hayatı sorgulayan bir tavırdır.

Cumalı, Garipçiler, İkinci Yeni Hareketi ve Toplumsal Gerçekçilerle birlikte aynı dönemlerde eserler vermesine rağmen kendi özgün tarzını kurduğunu ifade etmektedir. Bu çalışmada ele alınan Tufandan Önce örneği şairin bu beyanını doğrulayan bulgular ortaya koymaktadır. Örneklerde de görüldüğü gibi Cumalı, yer yer bahsettiği şiir hareketlerinden etkilenmiş olsa da, kendi özgün şiirini kurmayı başarmıştır. Cumalı, dörtlüler ya da beşlilerden oluşan, uyakları dize arasına sıkıştııılmış, içerik olarak da biçim olarak da ne yerli ne yabancı kendisinden önce gelmiş hiçbir şairi okura hatırlatmayan şiirlerini, başka şairlere benzetme yapılabilecekse şiirlerde önceliğin kendinde oluşunu özgün şiirinin örnekleri olarak göstermektedir (Hızlan, 1981, s. 7).

Cumalı'yı Orhan Veli, Oktay Rifat, Melih Cevdet'in ardından gelen kuşağın en iyi, en usta ozanlarından biri kabul eden Salihoğlu'nun Cumalı'nın şiirine dair tespiti de çalışmada elde edilen verilerle örtüşmektedir (Salihoğlu, 1968, s. 503):

\footnotetext{
reddeden, yan etkileri çok ağır olan yeni hayatın içinde bir daha dönebileceği baba ocağı olmayan, atılmıs gerçek bireyin tehlikeye girișini sorgulayan șiir. Canhıraș bir söylemin ve sosyal nefretin șiiri.

2. Hermetikler, imajinistler. (Tecrübe ve teknikle de bu işin olabileceğini göstermek istediler.)

3. Yahya Kemal, Ahmet Haşim, Asaf Halet, Necatigil, Turgut Uyar, Edip Cansever, takipçileri.

4. Hafız, Yahya Kemal, Necip Fazıl, Sezai Karakoç, İsmet Özel takipçileri. (Şiire de sirayet eden Türk-i̇slam Sentezi'nin mesajlarını verdiler. 3 nolu eğilimle iyi anlaştılar. Düzyazılarında T.D.K. jargonu kullanacak kadar iyi niyetliydiler.)

5. Kakafoniciler. (Duvar kültürünü şiire soktular. Tekerlemeyi ve meddahlığı şiirle karıştırdılar. Şiirde aliterasyonu yeni bir şey sandılar. Bu şiirin arka fonunda kuvvetli bir toplumsal eleştiri olduğundan yararı da zararı da olmadı.) 6. Yeni Bütünüler.

7. Edebiyat Dostları. (Marksist terminolojiyle şiiri açıklamaya kalkıştılar.)

8. Narkotik İmgeciler. (Bunlar halüsinasyonlarını yazdılar. Sahte düşlerin peşinden gittiler. Bireye karşı suç işlediler. İslenmiş ayıplarını ve günahlarını şiirle bastırdılar.)

9. Nevzat Çelik, Emirhan Oğuz. (Bu bir olgu şiiriydi. Ezik sola moral verdiler. 1980'lerden, 1985'e kadar yürekli şiirleri yazanları hesaba katmadılar. Bu şiir Ahmet Erhan'ın dediği gibi 1975'te başladıysa... 1978' de hapishane yıkıp 1981 'de şiirden yargılanan şairin toplumculuğu ne olacak.)

10. Gizli şairler. (Gizli Lonca'nın kurbanı olan bu şairler hep bir sonraki kuşağa kalırlar.
} 


\section{arts $=$}

1. Konuşma diline çok yakın düşen ama düzyazı edası taşımayan bir deyiş;

2. Beylik halk deyimlerini açıktan açığa kullanmaksızın, halk dili pınarından fışkıran bir yerlilik;

3. Duygusallığa düşmeyen bir içtenlik, bir duygululuk; bir çeşit Yeni-romantiklik;

4. Söyleyişinde ilk bakışta kolaylık gibi görünen, gerçekte ise derinliğine bir ustalığın belirtisi olan bir yerleşiklik, bir pürüzsüzlük.

Alver (2006, s. 110), edebiyat toplum ilişkisi bağlamında sanatçının döneme tanıklığının çalışmalarda öne çıkarıldığına dikkat çeker. Cumalı'nın 12 Eylül 1980 darbesi sonrasında yayımlanan bu eseri de seksenlerin travmatik durumlarına tanıklık etmekle kalmamış, kimi zaman öfke kimi zaman sitem dolu ifadelerle şiir okurunun zihninde soru işaretleri oluşturmayı da amaçlamıştır. Bu durum Alver tarafından da Cumalı'nın yalın, gösterişsiz, sade bir dil kullandığı, toplumsal sorunları işlediği şiirlerinde ise üslubunu sertleştirdiği şeklinde tespit edilmiştir (Alver, 2010, s. 29). Çalışma, edebiyat toplum ilişkisinin, sanatçı duyarlıı̆ının göz ardı edilmemesi gereken bir durum olduğunu, benzer çalışmaların farklı dönemlere ışık tutmak, ilgili dönemlerde sanatçıların bakışını ve tavrını ortaya çıkarmak adına da gerçekleştirilebileceğini de göstermekledir.

\section{KAYNAKÇA}

Alver, K. (2006). Edebiyat Sosyolojisi ve Hayat. Sosyoloji Dergisi, 15, 105-118.

Alver, M. (2010). Necati Cumalı'nın "Bozkırda Bir Atı”" Şiir Kitabının Dil ve Üslubu Üzerine. Türk Dili Araştırmaları Yıllığı - Belleten, 56 (2008/1) , 7-30

Bülbül, M, Türkoğlu S, ve Küzeci, D. (2015). Edebiyat ve Toplumsal İşlevi. Atatürk Üniversitesi Kazım Karabekir Eğitim Fakültesi Dergisi, 29, 1-11.

Cumalı, N. (1983). Bütün Şiirleri 1. İstanbul: Yazko.

Çelik, E. (2013). Edebiyat Eseri Toplumun Aynasıdır: Edebiyat ve Sosyoloji İlişkisi Üzerine. Türk Dili Dil ve Edebiyat Dergisi, CIV (738), 59-64.

Demir, F. (2015). 1980 Sonrası Türk Şiirinin Başlıca Tartışma Alanları. International Journal of Languages' Education and Teaching, 3, 144-163.

Gürbilek, N. (2001). Vitrinde Yaşamak 1980'lerin Kültürel Iklimi (3. Baskı). 
İstanbul: Metis.

Hızlan, D. (1981). Necati Cumalı, Çevremde, Yaşamımda Aradım Şiiri. Hürriyet Gösteri, 4, 6-8.

Kaplan, M. (1988). Şiir Tahlilleri I (10. Baskı). İstanbul: Dergâh.

Korkmaz, R. ve Özcan, T. (2006). "Cumhuriyet Dönemi: Şiir, 1950 Sonrası", Türk Edebiyatı Tarihi 4. Cilt (Editörler: Talat Sait Halman vd.). Ankara: Kültür ve Turizm Bakanlığı.

Moran, B. (1988). Edebiyat Kuramları ve Eleştiri (6. Baskı). İstanbul: Cem.

Okay, O. (1990). Sanat ve Edebiyat Yazıları. İstanbul: Dergâh.

Oktay, A. (1993). Cumhuriyet Dönemi Edebiyatı 1923-1950. Ankara: Kültür Bakanlığı.

Salihoğlu, M. (1968). Yeni Şïrimiz ve Necati Cumalı. Türk Dili, 203, 503- 508.

Sazyek, H. (2006). "Cumhuriyet Dönemi: Şiir, 1920-1950", Türk Edebiyatı Tarihi 4. Cilt. (Editörler: Talat Sait Halman vd.). Ankara: Kültür ve Turizm Bakanlığı.

Sever, M. (2019). 1980 Sonrası Türkiye'de Kültürel ve Toplumsal Değişme. Uluslararası Halkbilim Araştırmaları Dergisi, 2(3), 2-10.

Şengül, S. (2016). 1980 Kuşağı Türk Şiirine Eleştiriler. The Journal of Academic Social Science Studies, 52, 317-324.

Yıldırım, A. ve Şimşek, H. (2006). Sosyal Bilimlerde Nitel Araştırma Yöntemleri. Ankara: Seçkin. 